\title{
LA DISOLUCIÓN DE LA PRIMERA PERSONA EN EL CINE. TRES PELÍCULAS
}

\author{
Caleb Olvera Romero
}

Resumen:Enelartículosetrataycritica la relación queseestablece entre la construcción de la identidad y las estructuras narrativas. Se expone la crítica a esta estructura que han elaborado dos directores de cine contemporáneos, D. Lynch y D. Cronenberg, ambos con propuestas visuales que pretenden desestructurar la identidad a través de desestructurar la narración, resultado de esto son Lost Highway, Mulholland Drive y Spider, tres películas que parecen ser contadas desde los sujetos desestructurados y que presentan las alteraciones en la identidad por la pérdida de la narración.

Palabras clave: Disolución, identidad, desestructura, crítica, cine.

Enviado a dictamen: 04 de abril de 2011

Aprobación: 05 de mayo de 2011

Revisiones: 1

Caleb Olvera Romero, Doctor en Artes y Humanidades por la Universidad Autónoma de Zacatecas, Miembro del SNI, Docente investigador de tiempo completo en la UAZ, unidad de Psicología, Temas de especialización: Filosofía, estética, literatura y arte contemporáneo. Correo electrónico: calebor@hotmail. com.

120

Revista LiminaR. Estudios sociales y humanísticos, año 9, vol. IX, núm. 1, junio de 2011, San Cristóbal de Las Casas, Chiapas, México. ISSN: 1665-8027
Abstract: This article discusses and criticizes the relationship established between identity construction and narrative structures. It describes the criticism of this structure, this has been developed by two directors of contemporary cinema, D. Lynch and D. Cronenberg, both visual proposals seek the deconstruct of the identity through the narrative deconstructing, the result of this are films like Lost Highway, Mulholland Drive and Spider, these three films seem to be narrated from unstructured subjects that present alterations in their identities owing to the loss of narrative.

Key words: Disolution, identy, unstructured, criticism, cinema.

\section{La estética desestructurada de Lynch}

L a idea de la identidad se mantiene en la época romántica y sigue siendo central para la época moderna.

El concepto está todavía vivo en lo que respecta al arte, la literatura en primer lugar y especialmente la poesía, como una creación que revela o como una revelación que al mismo tiempo define y completa lo que pone de manifiesto (Charles, 1996: 441).

Las tendencias hasta la modernidad van a proyectar esta búsqueda de unificar un sujeto, en lo que se refiere 
a lo cognoscente, y encontrarán el desenlace de sus historias con el estructuralismo y más recientemente con las teorías del sujeto y la filosofía de la mente. El cine hará otro tanto.

Tanto Cronenberg como Lynch se inscriben en una estética disoluta y caótica, no importa ya lo que es tan obvio, esta verdad de desmontaje es una parodia, pues el yo nunca ha sido una estructura. Nunca ha existido una idea central que dé estructura y uniformidad al yo, ni siquiera la coherencia o la narración se mantiene, y sin embargo no podemos abandonar esta manera de interpretar el mundo.

En las películas de Lynch se nos presenta un orden distinto donde pululan hombres bestias, donde la historia se fragmenta para crear una semántica distinta, inversa. El yo habita en el lenguaje y la principal restricción del lenguaje es el sema, el significado que logra el entendimiento; en esa medida, Lynch hará las de deconstructor, pues apunta directamente al significado que coacciona el sentido de la película. La narración se asemeja en un punto a ese método dadaísta que se utilizó en poesía, donde se recortaban fragmentos de oraciones, se mezclaban en una bolsa y se sacaban al azar para crear la estructura (Cfr, Tristan, 1966: 23). Lynch hará algo similar, poniendo peculiar atención en limar los bordes y hacer parecer que se mantiene una secuencia, es como el carnicero que secciona el cuerpo humano morbosamente para enterarse de qué es lo que se encuentra dentro, aun a sabiendas de que lo único propio de su acto es la muerte, de que lo único que se encuentra una vez que se separan brazos y vientre es la realidad última de la existencia, la extinción. La propuesta estética del pintor-director no se reduce a la fotografía o al color, crea un horizonte, un dominio estético que va desde la ambientación hasta el maquillaje, selecciona el vestuario y la música. De hecho la música juega un papel importante en la estética de Lynch (Véase Hoks, 2010), sus obras avanzan obligadamente por un sendero, de la mano del espectador, de modo que ante el filme no se puede permanecer indiferente, nunca se cae en una propuesta pesimista, se guarda mucho de lo tétrico y presenta lo extraño. ${ }^{1}$ Es un director con una importante obra ${ }^{2}$ que trasciende los límites de lo narrable, pues lo narrable obedece a reglas semánticas.

\section{Lost Highway}

Lost Highway, 1996, representa lo que para muchos es la cumbre del cine negro. Lo cierto es que su estilo se venía advirtiendo desde antes con su primera película Eraserhead, 1976. En esta cinta se presenta la manipulación de la alteridad llevada al extremo, el Otro puede ser cualquiera, un recuerdo, un espejo e incluso la sombra. La oscuridad juega un papel importante en esto, pues existe dentro del filme un pasillo que desencadena la transformación de los personajes, mientras la oscuridad amenaza con tragárselos y vomitarlos diferentes. "Si bien es cierto que existen tipos de noches, las noches" (Djuna, 1993: 93), de Lost Highway son especialmente las más enfermas, violentas y salvajes. Se muestran las más repugnantes y sucias noches americanas, donde la decadencia de la cultura se pone de manifiesto, pero ahí los personajes son otros. Si su vida e identidad se constituyen en el día, en la noche cambiará radicalmente esto, pues son cubiertos de un misterio que les envuelve la psique y literalmente los hace otros con el tiempo. Es la transformación del sí mismo en el otro (Ricoeur, 1996: 12). La historia presenta el conflicto de Fred Madison, un saxofonista de jazz, y su esposa Renee, quien cierta mañana descubre un video ${ }^{3}$ en el cual se muestra la entrada de su casa, y se corta de pronto. Este evento desata un extraño conflicto casero por la pérdida de la identidad, que él resuelve manteniendo las cosas en calma; éste es su estilo, sabe que no tiene memoria para entender qué es lo que pasa, está indefenso ante cualquier situación, pues su memoria no le permite recordar casi nada, como ya lo advertía Sigmund Freud esta situación causa angustia y la angustia impotencia (Freud, 1993: 16). 
Carretera perdida es la historia de un asesinato causado por la impotencia, pero no la impotencia sexual de la que padece Fred, sino la impotencia mental de quien se siente traicionado y perdido entre sus recuerdos, de quien sabe que su peor enemigo habita en él mismo (Cfr. Cioran, 1997), de hecho ni siquiera sabe a qué se refiere cuando pronuncia: yo. No tiene una idea clara de quién es y por ello detesta las cámaras de filmar, que atrapan eso que él olvida y que pueden ser usadas en su contra. La cámara registra una realidad donde aparece el cuerpo de él, no él, es alguien más que hace y deshace como si se posesionara de su cuerpo, pero ni siquiera recuerda que alguien lo haya alienado. El miedo lo lleva a desarrollar no solamente un personaje extremo lleno de angustia y dolor. Para huir de este dolor desdobla su personalidad de manera inconsciente y crea otra identidad, que además construye un objeto de sus representaciones que será la viva imagen antropomorfizada de sus miedos encarnada en un extraño personaje negro.

\section{Fred como el otro de sí mismo}

La estética avanza entre negros que disuelven las imágenes y que posteriormente arrojan otro casete que filma no solamente la entrada de su casa sino también el interior de la misma, hasta llegar a su cama. Lo interesante es que Fred tiene un problema psíquico, una falla como los personajes de Cronenberg, sin embargo ésta no se manifiesta físicamente, sino en su memoria, no puede recordar a largo plazo las cosas, o mejor aún, las cambia y las combina. Lo que aparece como una sátira es el voltear a ver la narración que nos constituye, contada desde la memoria que de alguna manera juega el mismo juego que Fred, pues nos cambia y combina los recuerdos para hacer de nosotros otras personas, suponemos que somos los mismos por la identidad que poseemos, por el nombre, pero nuestros recuerdos cambian pues son interpretados a la luz de nuevos acontecimientos.
El yo es el ser más cambiante que existe ya que no posee un referente real, entendiendo esto como res, extensión o dureza. Ésta es la parte central de la trama, pues es él el que cuenta la historia, pero una historia combinada de manera siniestra que termina con el horror ante la muerte en la silla eléctrica. La historia de los fragmentos que constituyen la identidad de un esquizofrénico es puesta sobre la mesa. El video juega un papel importante por ser el principio de autoridad de lo que las cosas son, y aquí es tomado como criterio de verdad. La imagen siempre ha poseído una verdad que se filtra en el arte, en este caso en el cine. Cuando llega el segundo casete y se dan cuenta de que está filmado desde el interior de la casa llaman a la policía. La policía también juega un papel importante, pues bajo el anonimato del personaje, un actante sin nombre, con una personalidad ya establecida, se limita a meter presión en la débil estructura mental de Fred. ${ }^{4}$ Antaño había estado expuesto a la vigilancia de la policía y esto es parte importante para que se geste la fractura, la disolución, la presión; la impotencia y el dolor desatan finalmente el Mr. Hyde que lleva dentro el personaje principal (Véase, Stevenson, 2003: 45 y ss.).

La formación de la identidad se da en la cultura y la manifestación de la personalidad en la cultura tiene sus lineamientos de disolución: la religión, la fiesta, el alcohol, etcétera, son solamente algunos de los más conocidos. Fred va en busca de todo esto a la fiesta de su amigo Andy, pero en la fiesta liga los recuerdos. Estos fragmentos de recuerdos disparan con la fuerza de una catapulta la poca estabilidad de Fred, mezclando la realidad para crear nuevos recuerdos, que lógicamente constituirán un nuevo hombre. Fred lo proyecta fuera de sí, alucina un personaje con extraños poderes que de alguna manera es él mismo y el horror ante la muerte. No es el horror ante cualquier muerte, no es el temor a su muerte, sino a la muerte que puede infligir sobre los otros. Monta pues una escena que solamente ocurre en su cabeza y que dispara la alucinación de la castración ante su más ferviente miedo. Untestigo. A lo que más teme 
el personaje es al testigo, a alguien que finalmente pueda dar cuenta de las cosas como ocurrieron y ante el cual no se tienen armas, ante el cual la realidad es otra. Lo que somos se mantiene al margen de lo público, y este espacio privado se transforma en nuestro descanso, en nuestro principio de sanidad, nadie es capaz de vivir públicamente toda su vida. La idea de un dios que todo lo ve, incluso el interior de las personas, las vuelve locas. Fred, desde este tipo de locura, trata de armar su historia a pesar de que no puede recordar las cosas como suceden ante los demás y solamente tiene una sarta de pedazos inconexos que van hacia ningún lado y que no sabe de dónde provienen, pero que intenta rehacer por medio de un ideal, un alter ego que da cuenta de su actuar. ${ }^{5}$

Un personaje que filma todo, que es terrible, pues su mente fragmentada no podrá crear un alter ego benefactor, sino castrante que provenga de su impotencia. En este sentido el yo no soló se ve trasformado sino duplicado. ${ }^{6}$ Esta verdad de la fragmentación del yo del psicoanálisis, expuesta por Lacan (1984: 89), tiene en esta película su realización. Pero los fragmentos de la psique, más allá de la enfermedad del personaje, se salen de control, ya que el amigo imaginario de Fred, que antes se llamaba Peter, empieza a hostigarle. Lo hostiga al filmarlo, lo hostiga al presentarle ideas inconexas de las que sigue la traición de su mujer y el temor al gánster (Mr. Eddy). Nuestro personaje es más que un simple sujeto, es un torrente de angustia constante y su desenvolvimiento transcurre en una presión que mantiene la tensión de la película desde que comienza hasta que la silla eléctrica termina con su sufrimiento, que finalmente también es el comienzo, es la escena de un demente que llora y se culpa por no poder entender qué es lo que lo hizo cometer el asesinato de su mujer y del antiguo amante de ella.

Finalmente el tercer video muestra que la filmación se hizo desde el interior de la casa y llegando hasta la alcoba, además registra cómo Fred Madison está seccionando a su mujer que se encuentra ya en dos partes, dividida por la cintura, sin ofrecer resistencia alguna. Lo único que puede presentar a la cámara que registra lo que ocurre es la única verdad del filme, la división de la identidad y del cuerpo, la división de lo que en su más pura expresión da fe de nosotros mismos. Esta misma idea, con la que jugará Italo Calvino en Elvizconde demediado (1993), encuentra aquí una representación grotesca al estilo Lynch.

\section{La disolución de la historia}

En la celda sucede el rompimiento total, pues la angustia de la impotencia ante el rompecabezas hace su efecto, le rompe la cabeza a través del insomnio. Cosa bien sabida es que el insomnio prolongado causa esquizofrenia, y en este caso el insomnio y la angustia sirven de detonador de la disolución de Fred, que como resultado obtiene el regreso a su antigua personalidad de mecánico, Peter. Cuando a los 19 años es detenido por robo de autos y posteriormente, 5 años más tarde, es encarcelado de nuevo por un evento que susurra un crimen, el asesinato del pornógrafo Andy y del gánster Mr. Eddy; sus padres lo recogen en la cárcel y él regresa a una vida idílica, donde ahora mezcla de manera grotesca los recuerdos de esa época y su estar preso y condenado a la silla eléctrica.

"En el lejano, lejano oriente, cuando alguien es condenado a muerte se le manda a un lugar del bosque donde no puede escapar y tiene que esperar a su ejecutor sin saber a qué hora vendrá". ${ }^{7}$ Cuando llega, por lo general el condenado está muerto de angustia. En la Edad Media se sabía bien esto, una de las peores torturas consistía en lapidar a los condenados y éstos morían de desesperación. A Peter le sucede lo mismo, tiene tras de sí a la pandilla del gánster que sospecha su amorío con la mujer del jefe. Esto le pesa tanto que rompe con la realidad y tiene que matar al gánster. De la misma manera en que fantaseamos en salir de nuestros problemas con el asesinato de alguien, Peter lo hace, solamente que no controla la línea divisoria de lo real y lo imaginario, de hecho no es él quien mata a Mr. Eddy sino su alter ego que además lo filma, lo registra como 
una parte de sí mismo que quiere guardar, que quiere que se vuelva una piedra sólida de los cimientos de su nuevo ser.

La película está dividida en dos partes, pues la mente del protagonista presenta dichas dos partes: mecánicojoven, 24 años, de nombre Peter; y un tipo maduro de unos cuarenta, saxofonista, de nombre Fred. Su mujer, reflejo paranoide de la extrema huida, se tiene que cambiar el nombre para realizar la fuga de su antigua historia, esto da por efecto todavía un mundo más bizarro y oscuro, Patricia Arquette presenta un personaje de dos papeles, en principio amante de un gánster que la nombra Alice, y que después de la huida, huida de sí misma, de su vida, de su forma de ser, de su realidad, se liga de tal manera a los recuerdos de Peter que los disuelve con él, cambiándose de ciudad, de nombre, de profesión y de color de cabello; ahora obedece al nombre de Renee. Esto influye tremendamente en Madison, pues incapaz de recordar a largo plazo termina por estar con otra mujer, una que nada tiene que ver con Alice, la amante de un ser despiadado y cruel, de un ser con el poder de causarle mucho daño, ya no habita más el mundo de los recuerdos de él. Ahora está con otra mujer que aunque sigue siendo Patricia Arquette encarna el papel de ama de casa, de compañera del músico Fred Madison. Su memoria no dejará las cosas ahí, jugará de manera violenta con los retazos y alucinará con que las dos personalidades de su mujer en realidad constituyen dos mujeres distintas, de hecho en algunos momentos las alucina juntas. La trama es un duro golpe a la identidad del espectador, pues arroja igual que los personajes su cabeza contra el muro sólido de la incongruencia, se esfuerza lo mismo que Madison por reconstruir una historia desde una lógica que no le pertenece, que lo rebasa, de la misma manera en que la reconstrucción lineal y fiel de los recuerdos rebasa con mucho a todos. Cuestiona fundamentalmente nuestra identidad fundida en la temporalidad, en los recuerdos, recuerdos que son reconstruidos al antojo de esas fuerzas vitales que nos rebasan y que además son predatorias, la conciencia queda en entredicho, los occidentales ponen su fe en esta conciencia como si fuera capaz de mantener dentro del sótano a la bestia que llevamos dentro, sin saber que fuerzas oscuras de deseo son las que mueven la identidad a su antojo; somos en el más literal de los términos marionetas de estas fuerzas, disfraces con los que se cubre el deseo, deseo de guerra, de sexualidad, de poder, deseo ciego y voluptuoso, deseo de ser. ${ }^{8}$ Es esta metafísica tan intrascendente como la historia misma, tan superficial como la máscara que presenta el inconsciente ante una situación determinada, solamente para que no se sospeche su verdad ciega y aplastante. Esta película es un punto ciego en la carrera de Lynch, un punto sin retorno y sin comprensión, donde la imagen ha puesto en duda a la narración, donde es posible desprenderse de la narración para llegar a otra forma de apreciar el cine.

\section{La disolución de la identidad}

El ser-con-el-otro queda de manifiesto, el ser para el otro es fundamental, pues Madison es para Renee, mientras que ella no es sino para sí misma, pero a la vez también es para el miedo, pues su identidad es sacrificada por huir del gánster, huir de los recuerdos y de la forma de su historia; es un personaje que refleja la constante huida de sí mismo sin comprender que el dolor es la verdad insalvable de su existencia. Huye de sus circunstancias, intentando huir de sí, sin embargo esto no es más que otra manera de encontrarse con eso que la asusta, su yo.

La huida del sí mismo es llevada al extremo por esta película, la huida del dolor, del recuerdo, pues es el recuerdo lo único de lo que se puede en determinado caso - de manera falsa y somera- predicar la identidad. Decimos de manera falsa pues el recuerdo es interpretado de formas distintas en situaciones diferentes, es modelado por la memoria y cambiado por el tiempo, es trasformado en agradable o desagradable, las cosas como ocurrieron son devoradas por el tiempo, nuestra memoria solamente intenta apoderarse de 
instantes que va deformando para adaptarlos a una historia que nos hace soportable la verdad de la existencia. El trauma es quizá esta misma historia, pero con la dirección opuesta, un recuerdo que ha sido exagerado al grado de que su semántica ha adquirido un peso que no nos deja vivir, el psicoanálisis es una buena disolución de la primera persona, pues en el fondo lo que se hace es resignificar los recuerdos al momento de nombrarlos, armarlos de una manera distinta ya que la situación es distinta (Véase Malistako, 2001: 13 y ss.). Una persona después de algún tiempo de terapia cambia radicalmente lo que es, pues ha estado narrándose, ha estado reinventándose bajo una nueva luz. Fred no puede hacer eso, pues su mente no guarda recuerdos sino que los desarma, los transforma y los oculta, está siempre al punto de la ruptura, a un paso del olvido y se esfuerza por no perderlo todo en el más radical de los sentidos, pues este perderlo todo implica la pérdida del sí mismo.

El horror ante perder nuestra máscara, el horror ante perder la supuesta identidad y el principio de realidad. El mismo J. Lacan acepta que esto es una empresa imposible, nadie va a perder la imagen de sí ante otro (Cfr. Lacan, 2004:107). ¿Qué es lo que pasa cuando se pierde o se diluye la primera persona, cuando ya no queda máscara? ¿Qué es lo que se muestra? Sin embargo no contempló la enfermedad como dispositivo de disparo, pensó en las personas que tienen un principio de realidad al cual están atados tan indisolublemente como a la idea de identidad. Cuando se pierde la máscara ¿qué queda? Absolutamente nada, pues nunca ha habido un ser oculto, nunca ha habido un verdadero rostro, ${ }^{9}$ nuestra manera de estar en el mundo es el desplazarnos de posiciones discursivas, de emisiones lingüísticas, de unas a otras sin que exista un eje central, algo de lo que se pueda decir yo. Este yo es ese continuo disfraz que monta escenas y manifestaciones diferentes. Sin embargo, esto no lo sabe Fred, él esta aterrorizado ante la muerte de su mujer, ante un brutal asesinato que no recuerda y que su mente le sugiere imágenes en tercera persona, donde se ve a él mismo descuartizando a un ser demoníaco, que finalmente revela que es su mujer, igual que pasa en Las bacantes cuando Ágave mata a su hijo Penteo, pues piensa que es una bestia a la que está descuartizando (Eurípides, 2000: 297). No es sino su padre, en un pasaje que Freud reconoce como el más propiamente clínico de todos los pasajes, Cadmo - padre de Ágave-, que le devuelve la verdad del crimen, verdad de aletehia, pues le desoculta que ha descuartizado a su propio hijo sin saber que era él, y ahora presenta su cabeza ante su padre como muestra de su triunfo en la caza. Esta misma tragedia se repite, pero aquí no entra un principio supremo, aquí no es Dionisio el que lanza una maldición que se cumplirá por no reconocer su divinidad. No. Aquí el mal es insertado en el ser humano, es un mal terrenal y propio de la época, es un mal psíquico imposible de sospechar siglos atrás. ${ }^{10}$

Algo está mal en la mente de Fred. Algo que es detonado por los celos, el odio a sí mismo, la impotencia sexual, la angustia de ser, la melancolía de una vida que se perdió y que ahora ya no la encuentra, sobre todo por la castración mental a la que está sujeto. Busca su identidad como se busca un objeto que se ha puesto en algún lugar, Fred busca a Peter como si en cualquier momento se lo fuera a encontrar y así recobrar en un instante la identidad perdida, pero esto no sucederá, pues el dolor es la marca de Peter. De hecho, el disolvente de su identidad es el dolor, dolor insoportable que ha llevado a la ruptura y al asesinato, que los ha conducido a la huida no sólo de sus hogares, sino también de sus vidas, e incluso de sus yos, que en esos momentos habitaban. Son para el espectador radicalmente Otros, al grado de que el papel de Fred-Peter es interpretado por Bill Pullman y Balthazar Getty, dos hombres distintos de edades y complexiones, con un solo personaje que tiene dos nombres y que no logran saber por qué es el mismo.

Fred está obsesionado al máximo por conectar las piezas que le faltan para armar una verdad que no va a querer entender, la verdad del asesinato que se muestra 
en un tercer video que recoge la manera en que el mismo personaje entra a su casa los filma en la cama y comienza a matar violentamente a la esposa. En el instante siguiente él está en la cárcel pues lo hacen responsable de la muerte, y él no sabe qué pasó con esa muerte. Comienza el largo peregrinar de Sísifo, comienza la labor titánica de armar un rompecabezas donde las piezas no concuerdan, piezas que solamente muestran la muerte, una muerte que de hecho ha ocurrido y lo ha matado a él mismo varias veces. Reacomoda sus piezas pero no tiene juventud, no tiene recuerdos; sin embargo, en su juventud las cosas empeoraron con su novia y lo encerraron por robarse un carro, sentía la presión de ser el amante de la amante de un gánster, y su salud se estropeó a causa de esto, se enfermó a tal grado que su mente crea la fisura. Más adelante él tiene una vaga idea de la fisura, él no sabe de todo esto, pues esto solamente sucede ante el espectador, él está indefenso. Su cabeza da un giro espectacular creando otra personalidad que definitivamente lo suplanta. Siempre ha tenido miedo de lo que la cámara le muestra, pues la cámara por lo general le arroja a la cara una realidad que él no recuerda como sucedió, ya que su realidad es totalmente cambiada, de modo que su angustia y desesperación le llevan a cambiar no solamente los tiempos de lo real, sino la imagen de sí mismo. Ahora se percibe físicamente como antaño era, pero como no nos consta cómo era en su juventud, pues su mente no posee las imágenes sino que las deforma como las de todos nosotros, se concibe ahora joven, apuesto, fuerte, con una vida sexual más que activa y con todos los atributos que su alter ego le puede poner. La disolución de la identidad es total, no solamente suplantada en momentos sino superada y rehecha en otros, es una mezcla de tiempos y de ideas que no dejan vivir al personaje y que por lo general explotan y se salen del poco control en que las tenía el susodicho, para encontrar la miseria que es la única explicación que encuentra una y otra vez la fractura de la mente de Fred.

\section{Mulholland Drive}

En esta película se nos presenta la historia, o más precisamente las historias, de personajes que mantienen la belleza física hollywoodense, pero que están diseccionados en su memoria al grado de que no recuerdan quiénes son ni cómo se llaman. He aquí cómo es que Lynch logra plasmar la disolución de la primera persona, aquí ya no hay un yo, hay yos en todo el sentido del término. ${ }^{11}$ La chica guapa e inocente que cuenta la historia es presentada en principio bajo el nombre de Betty, pero irá cambiando de personalidad en la medida en que el dolor de la castración la va afectando. Hollywood es bastante inclemente contra los ingenuos que tienen sueños de estrellato. Si antes se intentaba ir al cielo, ahora se intenta ir a Hollywood. En esa media, la poética de sus películas critica ampliamente este nuevo estándar de trascendencia y belleza. El hombre en la pantalla es un hombre desproporcionado de lo que más lo hace ser él, y esto es la temporalidad en la que se encuentra sujeto. Esta certeza de su finitud resulta totalmente sesgada, pues el hombre plasmado en la celulosa se convierte en imagen atemporal, en imagen que no envejece, en imagen que muere y resucita en la siguiente película.

Sin embargo, esta transmutación de la persona no se había puesto tan en tela de juicio sino hasta que Lynch lleva a escena la fragmentación de la unidad. Sus personajes en ocasiones presentan risas extremadamente fingidas, símbolo grotesco que los emparenta con el gesto de agresión del animal. El animal muestra los dientes en desafío, las sonrisas de estas imágenes son totalmente simbólicas, no se terminan en ellas mismas sino que sugieren y son parte de la estética caótica que poco a poco va armando la estética del filme. Obsesionado con las deformaciones, Cronenberg desata una serie de películas que cuestionan altamente el orden moral y estético, ${ }^{12}$ sobre todo si mantenemos en mente que desde antaño se considera bueno lo que es bello (Kenevan, 2010). Pero la cuestión va mucho más allá, ya 
que Lynch por el contrario no está obsesionado con la deformación física, sino con la deformación psicológica. De hecho el secreto radica en hacer parecer que la trama la cuenta un esquizo, que revienta su cabeza contra el muro sólido de la incongruencia, tratando de manera fatua de entender un orden que se le escapa.

Nunca nuestros genes han dado para cubrir nuestras aspiraciones. Betty, la bella joven ingenua con aires de estrella de cine, se va transformando por el rechazo y la imposibilidad de audicionar, sus únicos papeles los logra porque le da lástima a su amiga. Amiga que finalmente se casa con el director por el que Betty siente una gran pasión. Poco a poco se le va descomponiendo la existencia, como antaño se le descompuso a Job, ambas historias son similares. ${ }^{13}$ En el relato de Job, no obstante, está el principio trascendente que guarda para sí la explicación de sus actos, y con ello la comprensión de su tragedia, aquí sin embargo no hay un dios que mantenga estable el aparato psíquico, aquí solamente hay castración y dolor. Contado desde una lengua torcida, desde una manera metonímica, pues en la cadena causal faltan eslabones que se han introducido en otro lugar de manera contranatural; Betty, casi al final de la película, no puede más que mandar matar a su amiga que es la verdadera estrella, es ella la que posee la vida que desea, es ella la que se casa con el director y la que logra los papeles. Este mandar matar sucede al final de la película, aunque se muestra al comienzo. De hecho comienza con esa escena, donde la Ryta, que terminará por llamarse Camila, no sin antes haber sospechado que se llamaba Daniel, es conducida en una limusina hacia un lugar de nombre Mulholland Drive, donde va a ser asesinada; un accidente automovilístico le salva la vida.

Se retoma la estética del circo, recordemos que no hay lugar más escabroso que el circo con su proporción de magia y embrujos, con su relación entre fiesta y decadencia. El dolor de la burla está presente, pero ahora es inverso, ahora la narradora se burla y ridiculiza el mundo de los negocios del cine, cómo es que se impone el dinero a la estética, cómo un arte que lucha por mantenerse dentro de los principios de la belleza, finalmente tiene que prostituirse para lograr realizarse (Hoks, 2010: 49). Éste es quizá el verdadero mundo donde se desarrolla la conformación de la primera persona, se muestra ridículo por cuestiones de impacto, se muestra agresivo ante una realidad que lo superó en discontinuidad, en ambivalencia, y que es mucho más grotesco de lo que podemos reflejar en nuestra interpretación. Interpretamos pedazos del mundo, pues nunca tenemos una visión total de los acontecimientos, nadie posee ese lugar en la luna desde donde pueda ver todos los actos de los hombres. La tiranía del director o escritor, su fuerza y su poder, radican precisamente en este lugar privilegiado, en usurpar y hacer parecer legítimo su estar en el trono del todo poderoso. Así la película muestra partes que solamente conoce el observador, pues el mundo sucede ante sus ojos, no como en la vida real donde el mundo escapa casi por completo a nuestros ojos. Aquí el director presenta y va armando, mostrando o sugiriendo las escenas para que todo logre la teleología que estaba implícita y hacia la cual corría toda la película desde el principio. Nuestros esquemas mentales nos hacen creer que esto son el mundo y la vida, una gran carrera de acontecimientos se suceden unos a otros para lograr un fin determinado. Nada más falso, pues esta metafísica de monos supone que hay un plan divino, miles de años solamente han arraigado en la psique del hombre la enferma idea de que todo tiene un final, una meta. Lynch va directamente contra esto.

La película se va construyendo de manera alternativa y en la edición es donde más se impone su tiranía, no ya de la manera antes descrita sino muy por el contrario juega las veces del demonio, en contra del plan divino. Es el destructor que desacomoda las piezas del aciago demiurgo y constantemente introduce el caos en nuestra historia. Mulholland Drive abandona la estética oscura y tétrica de Lost Highway, 
aunque mantiene similitudes como son las carreteras iluminadas por las luces bajas del automóvil y el dolor de quien intenta reconstruir una historia, que su misma mente le deshace y al mismo tiempo le sugiere que debe tener un orden diferente.

MulhollandDrive es mucho menos oscura y decadente, se burla de este lugar luminoso de los ricos de Estados Unidos, de su forma de vivir y de comer deprisa en los Winkiés. La sensualidad y el erotismo quizá son de los discursos menos entendidos en la teoría, aquí se ha presentado en pantalla un tratamiento distinto y sin embargo la sensualidad permanece en escena. La sexualidad contiene las normas y las reglas que constituyen más propiamente la psique humana, y sin embargo no es en la escuela donde se aprende lo permitido y lo no permitido, actualmente quien nos constituye es la imagen, somos sujetos-imagen con todo lo que esto conlleva de metafísica y de deconstrucción del sujeto. Nos enseñan a explorar la sexualidad y a reprimirla, lo que se puede mostrar y lo que no. Ante esta dinámica ya reaccionó $\mathrm{F}$. Bacon como un testigo de la carne que desestructura el cuerpo y mantiene la sexualidad (Eva Man, (2011), pero la obra de Lynch sigue dentro de la norma, aunque la sexualidad se ejerce con el cuerpo no tiene poco que ver la mente en ello. De hecho cuentan más las ideas, pues se tienen relaciones con la mente sobre el Otro, sobre la idea de dominio y territorio, sobre el pequeño sueño de matrimonio con final feliz. Pero en Lynch no hay nada de esto, todo lo contrario, la mente fracturada repite la sexualidad con ella misma, es el clon que se reitera buscando la autoerogenización, la autosatisfacción en un laberinto que no termina por comprender.

\section{Spider}

David Cronenberg, con este filme de 2002, deja atrás la larga historia de deformaciones físicas para internarse de lleno en una deformidad más atroz, la de la identidad. Spider es el nombre de un psicópata que después de pasar casi la mayor parte de su vida en un hospital psiquiátrico, al que ingresó de niño y del que ahora de adulto es dado de alta, regresa a su ciudad natal, donde se recluye en una casa de huéspedes. Comienza una tarea minuciosa igual a la de la araña que teje cautelosa una red (Guerrero, 2007: 7), donde atrapará los recuerdos. Intentará armar la explicación de lo que él es, guardando así una semejanza radical con la obra de D. Lynch. Spider es el apodo que su madre cariñosa, sobreprotectora, ${ }^{14}$ le da, ya que éste tiene la gracia de tejer telarañas con estambre y manos. La castración comienza justo cuando la sexualidad despierta. Spider vaga por las paredes de su habitación, vaga por las calles de su ciudad y va recopilando recuerdos, que anota en un diario. El diario jugará las veces de la memoria, lo que para Lynch es el video. El diario, símbolo del registro, no es otra cosa que la telaraña en que Spider intenta capturar su identidad. Lo arma y lo desarma, le quita y le agrega pasajes conforme éstos van sucediendo, finalmente siempre obtiene una historia incoherente, algo ahí no encaja, algo ahí falta o está cambiado. La historia que lo llevó ahí, el haber presenciado el asesinato de su madre, en manos de su padre, quien después con ánimo alegre la sustituye por una prostituta, tiene algo que no termina de convencerlo. De hecho, él no puede aceptar la sustitución de la madre, supuesto objeto de deseo del padre, por la prostituta, objeto real de deseo del padre. El amor es desviado por el hijo y la identificación del objeto del deseo se da en la mente de éste. A quien realmente ama el padre es a la prostituta, ergo la madre es la prostituta. Pero esto no lo puede permitir, así que inventa un ingenioso y milimétrico plan para deshacerse de su madre-prostituta, objeto del deseo del padre.

Utiliza su habilidad y teje una telaraña que va desde su cuarto hasta la cocina que se conecta justo con el regulador del gas. Cuando su madre llega cansada en la noche él sabe que se recuesta y duerme un poco en el sillón de la cocina, así que no tiene más que esperar, 
como lo hace una araña, que la víctima caiga en la telaraña. Así la trampa del niño funciona a la perfección, la madre ocupa su lugar en el sillón de la cocina y éste no tiene más que activar el regulador para dejar escapar el gas. El padre, en otra habitación, tarda lo suficiente para que el crimen se consume. La venganza de Spider ha terminado con el objeto del deseo del padre, la prostituta que ha suplantado a su madre y que tiene una sexualidad que él no puede aceptar en su madre. Así el padre, una vez que descubre el asesinato de la madre, llorando, no le queda otra que recluir a Spider en un psiquiátrico.

Años más tarde, cuando Spider sale, se encuentra vagando por las calles de su ciudad natal en busca de esa verdad que desea con toda su alma, y que nosotros sabemos que no quiere encontrar, pues el dolor es otra vez el disolvente de la identidad que lo llevó a la locura, a la alucinación..$^{15}$ Lo que es de esperarse que ocurra, ocurre. Spider logra después de algunas décadas armar el rompecabezas. Antaño, en el sanatorio, recuerda que una vez alguien rompió un vidrio del que él agarra un trozo para suicidarse, y que finalmente lo regresa sin lograr su cometido. El doctor a cargo aceptó el trozo y lo colocó justo en la parte del vidrio que ahora yace sobre una mesa, esperando ser armado y al que ahora solamente le resta ese pedazo. Spider hace de esta escena su método, busca en su memoria, en su ciudad, en sus antiguos lares los pedazos de su historia, hasta que finalmente encuentra el último. La verdad queda al desnudo, mostrando su sensualidad de puta aterradora. La verdad que no quiso ver de niño ahora le es arrojada a la cara por una circunstancia más que accesoria. Su madre nunca fue suplantada por la prostituta. El cambio solamente ocurrió en su mente y él es el verdadero asesino de su madre.

Décadas ha estado luchando contra la disolución de su yo para armar una identidad que de pronto y por instantes consigue, pero esta verdad es tan dolorosa que lo vuelve a disolver. La verdad del espejo completo le recuerda esa sexualidad que le espanta, le refleja la verdad de su asesinato y como esto es insoportable, la identidad solamente se mantiene por segundos, dando como resultado de nuevo la fragmentación, aunque esta vez es aún más dolorosa y grotesca, al grado de que regresa a un estado casi catatónico y es nuevamente recluido en un sanatorio.

Nuestra frágil idea de la identidad descansa, como en el caso de Alice, en una fuga del dolor, sin embargo este filme trastoca los papeles, ya que la disolución se da precisamente porque la identidad es dolorosa y la disolución es la única manera que encuentra el psicópata para soportar su verdad de fragmentos.

\section{Notas}

${ }^{1}$ Se pueden rastrear parte de sus influencias sobre todo en Terciopelo azul, donde las imágenes de los insectos parecen sacadas de un filme de Buñuel.

${ }^{2}$ Su obra consta de Cabeza borradora (Eraserhead), 1976. El hombre elefante (The Elefant Man), 1980. Dune (Dune), 1984. Terciopelo azul (Blue Velvet), 1986. Corazón salvaje (Wild at Heart), 1990. (Twin Peaks: Fire Walk with Me), 1992. Carretera perdida (Lost Highway), 1996. Una historia verdadera (The Straight Story), 1999. Sueños, misterios y secretos (Mulholland Drive), 2001. (Inland Empire), 2006. Además para TV ha realizado Twin Peaks, Hotel Room, entre las más conocidas.

${ }^{3}$ Videodromo es una película que marcará la necesidad de introducir el video como un elemento fundamental de la estética de Cronenberg a la que Lynch tiene muy en cuenta y le sirve para representar por lo general el mundo del arte, de la imagen y su relación con una memoria fatua.

4 Es interesante resaltar cómo es que se pueden repetir rasgos y personajes, roles sociales, donde las características son estandarizadas como parte de la personalidad laboral. Los uniformes son solamente el elemento exterior, psicológicamente también existe una uniformidad en los policías, en los asesinos y demás. 
${ }^{5}$ Interesante recurso narrativo que siempre está presente en la literatura y que consiente en crear un alter ego que sea nuestro aliado o nuestro enemigo (véase Conrad, 1996).

${ }^{6}$ La idea de un doble especular la encontramos ya en Dostoyevski, en su segunda obra de título El doble, ver Obras completas, (1991). Dicha metáfora la hemos visto una y otra vez en el cine, como en El Club de la Pelea, o más recientemente en El Cisne Negro, etcétera.

${ }^{7}$ Parte de los diálogos de la película Lost Highway.

${ }^{8}$ Quizá esta es la única vedad que late detrás del psicoanálisis, la idea de que somos marionetas de nuestras pasiones. (Guggenheim, 1999: 209).

9 Esta problemática se encuentra introducida en el psicoanálisis por vía de Freud, pero la tenemos ya en Nietzsche, quien llama la atención una y otra vez sobre la noción de Marcara como constituyente del sujeto, además sobre esta misma línea Vattimo elabora su libro, El sujeto y la máscara, Nietzsche y el problema de la liberación, (2003).

${ }^{10}$ Véase Bertnard, (1996), interesante introducción al concepto de mal, pues también es un concepto histórico con semánticas particulares.

${ }^{11}$ Problemática ya tratada por Lacan (1984: 867).

${ }^{12}$ Ver por ejemplo Shiver, 1975, o Rabia, 1976, en esta última la heroína, después de una operación quirúrgica, desarrolla en la axila una punta orgánica en forma de pene, que tan solo con sangre humana puede aliviar su hambre voraz. Citado en Cortés (1999: 188).

${ }^{13}$ Crf. Libro de Job, 2001, México: Editorial Promexa.

${ }^{14}$ Son interesantes estas categorías, ya que desde un principio se plantea la dimensión psicoanalítica que jugarán los personajes de la película. Más que al análisis freudiano, obedecen a la lógica lacaniana, pues no se trata tanto del padre y la madre, sino de roles o funciones que se ven encarnados por distintos personajes.

${ }^{15}$ Lo mismo pasa con el personaje de Dostoyevski (1991: 304), J. P. Goliadkin, quien por vergüenza y dolor crea un doble para salir de la realidad o simplemente para soportarla.

\section{Bibliografía}

Guerrero, Antonio A. (2007), Paciencia de araña, México: Filos de agua.

Bertnard, Sichère (1996), Historias del mal, España: Gedisa. Calvino, Italo (1993), El Vizconde de mediado, España: Ciruela.

Charles Taylor (1996), Fuentes del yo, España: Paidós.

Cioran, M. (1997), Oeuvres, Francia: Gallimard.

Conrad J. (1996), El corazón de las tinieblas, México: Universidad Veracruzana.

Cortés, José Miguel G. (1999), Orden y caos, un estudio cultural sobre lo monstruoso en el arte, España: Editorial Anagrama, p. 188.

Djuna Bernes (1993), El bosque de la noche, Barcelona: RBA.

Dostoyevski (1991), Obras completas, México: Editorial Aguilar.

Eurípides (2000), Tragedias, vol. III, Madrid: Editorial Gredos, p. 297.

Freud, S. (1993), Obras completas, Buenos aires: Amorrortu. Guggenheim, P. René (1999), Cine y psicoanálisis, Bogotá: PMF.

Hoks, Roy (2010), Cinematic Projections: The Analytical Psychology of D. Lynch. New York: Moton.

Lacan J. (2004), "El fenómeno psicótico y su mecanismo", en Escritos, Buenos Aires: Paidós.

Lacan, J. (1984), "La metáfora del sujeto", en Escritos, México: Siglo XXI, p. 867.

Eva Man, K. W. (2011), Reclaiming the Body: Francis Bacon's Fugitive Bodies and Confucian Aesthetics on Bodily Expression, en http://www.contempaesthetics.org/newvolume/ pages/article.php?articleID=23, [mayo de 2011].

Kenevan, Clive G. (2004), History of esthetic, New York: Brandon Books.

Libro de Job (2001), México: Promexa.

Malistako, P. K. (2001), Lavisión del psicoanálisis, Argentina: Prensa Unida.

Stevenson, R. L. (2003), Dr. Jekyll y Mr. Hayde, México: Editorial Tomo.

Ricoeur, P. (1996), Sí mismo como otro, México: Siglo XXI. 
Tristan Tzara (1996), Primer manifiesto dadaísta 1918, Buenos Aires: Logos.
Vattimo, Gianni (2003), El sujeto y la máscara, Nietzsche y el problema de la liberación, Barcelona: Península. 